\title{
Spor Bilimleri Öğrencilerinin Liderlik Davranışlarına İlişkin Öz Algıları ile Yaratıcı Kişilik Özellikleri Arasındaki İlişki*
}

\author{
The Relationship Between Self-Perceived Leadership Behaviors and \\ Creative Personality Traits of Undergraduates Who Study Sports Sciences
}

\author{
Nurdan GÖKBARAZ ${ }^{* *}$ iD \\ Elif BOZYİĞİT ${ }^{* * *}$ iD \\ Hüseyin GÖKÇE ${ }^{* * *}$ iD
}

Öz

Araştırmanın amacı spor eğitimi alan üniversite öğrencilerinin liderlik davranışlarına ilişkin öz algıları ile yaratıcı kişilik özellikleri arasındaki ilişkiyi incelemektir. Bu çalışma, genel tarama modelinde ve nicel veriler elde edilecek şekilde tasarlanmıştır. Araştırmaya Beden Eğitimi ve Spor Öğretmenliği, Antrenörlük Eğitimi, Rekreasyon ve Spor Yöneticiliği bölümlerinde öğrenim gören ve yaş ortalaması 21.78 \pm 3.016 olan 236 üniversite öğrencisi (kadın=74, erkek=162) katılmıştır. Araştırmada veri toplama araçları olarak; kişisel bilgi formu, "Lisans Öğrencilerinin Liderlik Davranışlarına İlişkin Öz Algı Ölçeği” ve "Yaratıcı Kişilik Özellikleri Ölçeği” kullanılmıştır. Verilerin değerlendirilmesi için bir istatistik programı kullanılmıştır. Analizler için betimsel istatistikler ve korelasyon tekniklerinden yararlanılmıştır. Spor bilimleri eğitimi alan üniversite öğrencilerinin liderlik davranışlarına ilişkin öz algıları ile yaratıcı kişilik özellikleri arasında bazı boyutlar açısından orta düzeyde, pozitif ve anlamlı ilişkiler vardır. Sonuç olarak, öğrencilerin liderlik davranışlarına ilişkin öz algıları ile yaratıcı kişilik özelliklerine ilişkin puanların beraber arttığı söylenebilir. Anahtar Kelimeler: Liderlik davranışları, öz algı, yaratıcı kişilik, spor bilimleri, öğrenci

\section{Abstract}

The aim of the study is to examine the relationship between the self-perception of leadership behaviors of university students who receive sports education and their creative personality traits. This study was designed in general screening model and in a way to obtain quantitative data. 236 university students (female $=74$, male $=162)$ studying in Physical Education and Sports Teaching, Coaching Education,

* Bu çalışma 25-28 Nisan 2019 tarihleri arasında Alanya-Türkiye’de düzenlenen 2. Uluslararası Herkes İçin Spor ve Wellness Kongresinde sözel bildiri olarak sunulmuştur. Bu çalışmada kullanılan verilerin 2020 yıl öncesine ait olduğu ve etik kurallara uyulduğu araştırmacılar tarafindan onaylanmıştır.

* Yüksek Lisans Öğrencisi, Pamukkale Üniversitesi, Sosyal Bilimler Enstitüsü, gkbarazn@gmail.com, https://orcid.org/0000-0002-6621-8155

*** Doç. Dr., Pamukkale Üniversitesi, Spor Bilimleri Fakültesi, ebozyigit@gmail.com, https://orcid.org/0000-0001-9557-6106

**** Doç. Dr., Pamukkale Üniversitesi, Spor Bilimleri Fakültesi, hgokce@pau.edu.tr, https://orcid.org/0000-0001-9250-0317 
Recreation and Sports Management departments and having an average age of $21.78 \pm 3.016$ participated in the study. As data collection tools in research; Personal Information Form, "Self-Perceived Leadership Behaviors of Undergraduates Scale" and "Creative Personality Traits Scale" were used. A statistics program was used to evaluate the data. Descriptive statistics and correlation techniques were used for analysis. There was a moderate, positive and significant correlation between the self-perceived of leadership behaviors and creative personality traits of sport sciences undergraduates in terms of some dimensions. As a result, it can be said that students' scores of self-perceived of leadership behaviors and creative personality traits increased together.

Keywords: Leadership behaviors, self-perceived, creative personality, sports science, undergraduate

\section{Gíriş}

Liderlik, yönetim alan yazınında oldukça ilgi çeken ve üzerinde çok durulan konulardan biri olarak görülmektedir. Bu bağlamda geçmişten günümüze klasik ya da çağdaş yaklaşımlar olarak alan yazında çok sayıda liderlik modeli ve liderlik ile ilgili oldukça fazla bilimsel çalışmaya rastlanmakta ve her geçen gün merakla ortaya çıarılan araştırma konuları bulunmaktadır.

Günümüzde toplumların, kurumların, örgütlerin giderek çeşitlenmesi üzerine de eğitimde, iş ve sanayi alanında, sporda kısaca toplumun her kesiminde ihtiyaç duyulan liderlik, mevcut koşullara göre içeriği ve anlamı farklılaşan tarihi çok eskilere dayanan çağdaş bir kavram haline gelmiştir (Scott, 2014; Özbek ve Kızılyallı, 2017). Liderlik, birçok kez bireysel özellikler, lider davranış etkileşim kalıpları, rol ilişkileri, takipçi algıları, takipçi üzerindeki etkisi, görev hedefleri üzerindeki etkisi ve örgüt kültürü üzerindeki etkisi açısından tanımlanmıştır (Yukl, 1989). Liderlik ile ilgili tanımlara bakıldığında Stogdill’e (1974) göre, fikir birliği ve karşılıklı davranış ile yapının harekete geçirilmesi ve devam ettirilmesi, Değirmenci'ye (2012) göre ise yaratıcllı, analitik düşünme, problemlerle başa çıkabilme, yenilik ve değişim anlamlarına gelmektedir. Liderlik, insanların davranışlarını kendi isteği doğrultusunda etkileyen ve bu eylemini gerçekleştirirken yol gösteren, aydınlatan, ileriyi gören, birlikte çalıştığı kişilerin istek ve ihtiyaçlarını zamanında sezen yaratıcı kişilerde olan bir yetenektir (Bakan, 2008). Liderliğin doğasını içeren birçok alan olduğu gözlemlenmiş ve liderliğin içeriğini anlamak için yapılan çalışmalarda birçok yaklaşım/kuram ortaya çıkmıştır ve çıkmaya devam etmektedir.

Değişen iş dünyası, gelişen teknoloji, bilginin üretim şekli ve etkin bir şekilde kontrol edilmesi ihtiyacı, rekabetin artması, yönetici/lider ve örgüt davranışı gibi konuların ön plana çıkmasına ve bununla birlikte birçok liderlik kuramının ortaya konmasına neden olmuştur. Liderlikle ilgili kuramları; özellikler yaklaşımı, davranışsal yaklaşım, durumsal yaklaşım ve modern/çağdaş yaklaşımlar olmak üzere dört grupta toplamak mümkündür (Bozyiğit, 2019; Özbek ve Kızılyallı, 2017). Liderlik özelliklerinin çoğunun aynı anda bir kişide bulunamaması ve bu özelliklerin kolaylıkla ölçülememesi, liderlikle ilgili yeni arayışları gündeme getirmiştir. Yapılan çalışmalarda modern çağın gereklerine uygun olarak, değişen liderlik davranışları ele alınmaya başlanmıştır. Bunun üzerine liderin sahip olduğu özellikler yerine izleyicilerin özelliklerine ve liderin nasıl davrandığı konusuna ağırlık verilmiş ve ortaya "Davranışsal Liderlik Teorisi” çıkmış ve bu konuda oldukça fazla araştırma kuramları ortaya atılmıştır (Tengilimoğlu, 2005; Bozyiğit ve Sartık, 2018; Mutlu ve diğ., 2020). 
1940’larda liderlik sürecini açıklamaya çalışan davranışsal yaklaşımlar, liderleri başarılı ve etkin yapan unsurun liderin özelliklerinden çok liderlik süreci içerisinde sergilediği davranışları olduğu ana fikrini savunmaktadırlar (Bozyiğit, 2019). Davranışsal yaklaşım çalışmaları kapsamında, liderin neyi nasıl yaptığına odaklanılmış ve liderlik sürecinde kişisel özelliklerden ziyade liderin davranışı önem kazanmıştır (Kızıloğlu ve diğ., 2012). Davranışsal yaklaşımda yazarların da belirttiği gibi liderin kişilik özelliklerinden ziyade davranışları ele alınmış olsa da gelişen iş dünyası ve teknolojinin hızlı ilerleyişiyle liderleri ayıran kişilik özelliklerinin ön plana çıkmaya başladığı söylenilebilir.

Örgütsel davranış bilimcilerine göre liderlik, bir grup içerisinde yer alan bir bireyin yine grup içerisinde oynadığı role ve bu rolün diğer grup üyelerinin beklentilerini biçimlendirmesine dayanan karşılıklı etkileşim süreci içinde oluşmaktadır. Grup içerisinde gösterilen bu davranışların, bireyin kişilik özelliklerinin dışa vurulması ya da yansıması olduğu söylenebilir. Farklı kişilik özellikleri taşıyan bireyler belli durumlarda farklı davranışlar (tepkiler) sergileyebilirler (Burke ve Litwin, 1992). Zel (2002) insanı anlamanın zor ve karmaşık bir süreç olduğuna değinerek, örgütsel performansın artması için çalışanların etkin, verimli kullanılması gerektiğini ancak kişilik ile liderlik tarzları arasındaki ilişkinin ikinci planda kaldığını vurgulamıştır. Yapılan bir araştırmada yöneticilerin hiyerarşik yapının her hangi bir birimine yönetici atarken kişilik faktörünün dikkate alınarak yapılmasının örgüt ya da kurumların lehine olacağı belirtilmektedir (Korkmaz, 2006). Liderlik davranışlarının kişilik özellikleriyle bire bir bağlantısı olduğu düşünüldüğünde günümüz iş dünyasında "yaratıcı kişilik özelliği” bir liderde bulunması gereken önemli kişilik özelliklerinden biri olarak sayılabilir. Bu bağlamda, Bakan’ın (2008) tanımında liderlikten, bireylerin davranışlarını kendi isteği doğrultusunda etkileyen ve bu doğrultuda yol gösteren, onların isteklerini ve ihtiyaçlarını önceden tahmin eden, aydınlatan ve vizyon sahibi bir yaratıcı kişilik yeteneği olarak bahsedilmektedir. Çağdaş organizasyonlarda birçok projenin en yeni ürün, hizmet ve süreç ya da en yeni çalışma yöntemleri geliştiren hem üretken hem de yaratıcı olmaya çalışan profesyonel ekipler tarafından yapıldığı ve insanların bu kuruluşlardaki çalışma ortamını en iyi etkileyen, tüm güçlerde en hızlı ve en güçlü olan kişinin bu ekiplerin "lideri” olduğu bilinen bir gerçektir (Amabile ve diğ., 2004). Erçetin (2000) örgütlerin yönetim anlayışlarının yönlendiricilik, etkileyicilik ve yaratıcılık gibi liderlik süreçleri içermesi gerektiğini belirtmekte, Atar ve Özbek (2009) de örgütlerin temel görevinin yönetim işini üstlenecek lideri keşfetmek ve görev başına getirmek olduğunu ifade etmektedirler. Günümüz şartlarında bir liderde bulunması gereken en önemli özelliklerden birinin yaratıcı kişilik özelliği olduğu göz önüne alındığında yaratıcılık kavramını yakından ele almanın oldukça önemli olduğu düşünülmektedir.

Türk Dil Kurumu’nun (TDK, 2020) 1974 yılında yayımladığı Eğitim Terimleri Sözlüğünde yaratıcı düşünme kavramı "buluşçu, yenilik arayan ya da eski sorunlara yeni çözümler getiren ve özgün düşüncelerin ortaya çıkmasını sağlayan bir düşünme biçimi” olarak tanımlanmıştır. Yaratıcılık, insan ihtiyaçlarının karşılanması uğrunda yapılan yenilikçi, kazanılmış ilgi alanlarına dayanan çalışmalar sonucu elde edilen ilklerdir (Değirmenci, 2012; Sternberg, ve diğ., 2003). Yapılan bir araştırmada bireylerin farklı alanlardaki yaratıcılıkları incelenmiş ve bu bireyler; içgüdüsü ve güzel duyuları yüksek, farklı bakış açılarına sahip ve zengin ilgi alanları olan, risk alan, bağımsız karar veren, aktif, öz güvenli ve sorgulayıcı kişiler olarak tanımlanmıştır (Barron ve Harrington, 1981). Yaratıcılık, yeni, 
farklı ve diğer bireylerde görülmeyen formlarda düşünme yeteneğidir. Yaratıcılık ve yaratıcı problem çözebilme yeteneği ise vizyon sahibi bir liderde olması gereken başlıca özelliklerdendir (Bosiok, 2013; Türksoy, 2008). Şahin ve Danışman (2017) yaratıcı kişilik özelliklerini orijinal düşünme, yaratıcı farkındalık, mantıksal olma, sıra dışı düşünme, gelişmiş sorgulama becerileri, bilgi ve tecrübe sahibi olma, risk alabilme, meraklı olma, bilinmeye karşı ilgi duyma, gelişmiş hayal gücü, açık görüşlülük, sezgisel ve gelişmiş etik değerlere sahip olma gibi maddeler ile özetlemişlerdir. Alan yazında liderlik ve yaratıcılık ile ilgili tarama yapılırken "yaratıcı liderlik" kavramı da görülmüştür ve yaratıcı liderlik ile ilgili yerli ve yabancı birçok çalışmaya rastlanılmıştır (Uzunçarşılı ve Özdayı, 1997; Öztürk ve Zembat, 2015; Şahin ve Danışman, 2017; Keskin ve Gündüz, 2019; Basadur, 2004; Stoll ve Temperley, 2009a; Soemartono, 2014; Rolling Jr, 2016). Yaratıc liderlikten de kısaca bahsedecek olursak, yaratıc1 liderlik, her düzeyde öğrenmeyi engelleyen problemlere ve zorlu konulara yaratıcı düşünülmüş bir yanıttır. Yaratıcı liderler başkalarının da yaratıcı olması için koşulları, ortamı ve fırsatları da sağlayan kişilerdir (Stoll ve Temperley, 2009b). Yaratıcı liderlik, değişime ayak uydurmayı sağlayacak stratejik kıvraklığa, yaratıcı zekaya ve esneklik yeteneklerinin artırılması kapasitesine, yapısal, teknolojik ve sosyal konularda yenilikler yapabilme kapasitesine sahip bir bireyi tanımlamaktadır (Keskin ve Gündüz, 2019). Yaratıcı liderlik, kolektif ve kültürel başarı için bir araçtır. Hepimizin daha az yalnız, daha az savunmasız olmasını sağlamak için kaynaklarımızı adapte etmemize, bağlamamıza, ilişkilendirmemize, güçlere katılmamıza ve bir araya getirmemize izin veren yaratıcı etkinlik sürekliliğini üreten bir tür zeka biçimidir (Rolling Jr, 2016). Demir Uslu’ya (2011) göre ise yaratıcı liderlik, hızlı karar veren, risk alabilen, karmaşıklığın yönetilmesinde, gizlenmesinde veya ortadan kaldırılmasında tamamen farklı varsayımları temel alabilen bireylerin sahip olduğu liderlik davranışıdır.

Günümüz koşullarında daha etkili, daha yaratıcı, daha yenilikçi ve hızlı kararlar alabilen liderlere sahip olmanın daha iyi bir toplum ve daha iyi bir dünya oluşturmak için önemli olduğu ve bu özelliklere sahip liderlerin gelişiminde eğitimin, bilhassa üniversite deneyimlerinin kritik bir parça olduğu düşünülmektedir. Astin ve Astin (2000) liderlik gelişiminin önemli ve yararlı olduğunu savunmuş, üniversite eğitimindeki liderlik gelişiminin lisans deneyimini zenginleştirdiği, öğrencileri güçlendirdiği ve yaşamları üzerinde daha fazla kontrol hissi verdiğini belirtmişlerdir. ZimmermanOster ve Burkhardt’a (2000) göre üniversiteler müfredat ve eş müfredatlar aracillğıyla liderleri işe almak ve geliştirmek için zengin firsatlar sunmaktadır. Ortak müfredat deneyimleri sadece öğrencilerin resmi sınıf ve müfredat deneyimlerini desteklemek ve arttırmakla kalmaz, aynı zamanda kuruma veya topluma hizmet veren ortak grup projeleri yoluyla liderlik gelişimi için güçlü öğrenme firsatları yaratabilmektedir.

İlgili alan yazına dayanarak bu araştırmanın amacı, spor bilimlerinde eğitim alan lisans öğrencilerinin liderlik davranışlarına ilişkin öz algıları ile yaratıcı kişilik özellikleri arasındaki ilişkiyi incelemektir. $\mathrm{Bu}$ amaçla, lisans öğrencilerinin liderlik davranışlarına ilişkin öz algıları ile yaratıcı kişilik özellikleri arasında anlamlı bir ilişki olup olmadığı araştırmanın problem cümlesini oluşturmaktadır. 


\section{YÖNTEM}

Araştırma Modeli: Araştırmada kaynak belgelerin incelendiği ve sayısal verilerin kullanıldığı nicel araştırma yöntemlerinden var olan bir durumu betimlemeyi amaçlayan tarama yöntemi kullanılmıştır (Karasar, 2012).

Araştırma Grubu: 2018-2019 eğitim öğretim yılında Pamukkale Üniversitesi, Spor Bilimleri Fakültesi’nde öğrenim gören 496 öğrencinin 236’sı araştırmaya gönüllü olarak katılmıştır (kadın $\mathrm{n}=74$, erkek $\mathrm{n}=162$ ). Kolayda örnekleme yönteminin kullanıldığı araştırmaya katılan öğrencilerin

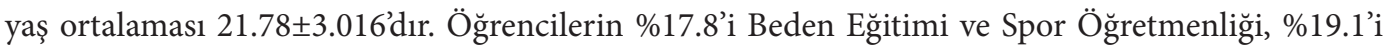
Antrenörlük Eğitimi, \%19.9’u Rekreasyon ve \%43.2’si Spor Yöneticiliği eğitimi almaktadır.

Veri Toplama Araçları: Araştırmada veri toplama araçları olarak Özbek ve Kızılyallı (2017) tarafından geliştirilen "Lisans Öğrencilerinin Liderlik Davranışlarına İlişkin Öz Algı Ölçeği” (LDİÖAÖ), Şahin ve Danışman (2017) tarafından geliştirilen "Yaratıcı Kişilik Özellikleri Ölçeği” (YKÖÖ) ve Kişisel Bilgi Formu kullanılmıştır.

"Lisans Öğrencilerinin Liderlik Davranışlarına İlişkin Öz Algı Ölçeği” 20 madde ve dört alt boyuttan oluşmaktadır. Alt boyutlar; "katılımcı lider, kendine güvenen lider, ilkeli lider ve kararlı lider" şeklindedir. 5’li Likert türü olan ölçek ifadelerine verilen yanıtlar "hiç katılmıyorum” ve "tam katılıyorum" şeklinde 1 ile 5 puan arasında derecelendirilmektedir. Alt boyutlar içinde artan puanlar, öğrencilerin liderlik öz algılarının olumlu olduğunu göstermektedir. Ölçeğin Cronbach’s alpha değerleri ölçeğin geneli için .91, alt boyutları için "katılımcı lider" .81, "kendine güvenen lider” .70, “ilkeli lider” .82 ve "kararlı lider" .74’tür.

"Yaratıcı Kişilik Özellikleri Ölçeği” 17 madde ve dört alt boyuttan oluşmaktadır. Alt boyutlar; "amaç yönelimlilik, içsel motivasyon, merak ve risk alma” şeklindedir. 5’li Likert türü olan ölçek ifadelerine verilen yanıtlar "kesinlikle katılmıyorum" ve "kesinlikle katılıorum" şeklinde 1 ile 5 puan arasında derecelendirilmektedir. Uygulama formunda ters puanlanan maddeler bulunmaktadır. Ölçme aracından her alt boyut için ayrı puan elde edilebileceği gibi toplam puan elde edilerek de kullanılabilir ve toplam puan için en düşük puan 17 , en yüksek puan ise 85 'tir. Puanlar yükseldikçe ölçülmesi hedeflenen özellik yükselmekte, tam tersi durumda ise gözlenen özellik daha az ortaya çıkmaktadır. Ölçeğin Cronbach's alpha değerleri genel ölçek için .67, alt boyutları için "amaç yönelimlilik" .65, “içsel motivasyon”.60, “merak" .64 ve "risk alma” .64’tür.

Veri Toplama Yöntemi: Öğrenciler ile derslik ortamında görüşülerek, önce araştırmanın önemi ve veri toplama araçları hakkında bilgi verilmiş, gönüllü katılım sağlayan öğrencilerden onay alınmış ve daha sonra ölçek formları öğrencilere uygulatılarak veriler toplanmıştır.

Verilerin Analizi: Verilerin analizinde SPSS 21 paket programı kullanılmış, betimsel istatistikler ve Pearson Korelasyon katsayıları hesaplanmıştır. Korelasyon katsayısının hesaplanması ilişkinin miktarı konusunda yorum yapabilmek için kullanılmaktadır. Korelasyon katsayısı (r), iki değişken arasındaki ilişkinin ölçüsüdür ve -1 ve +1 arasında değişim gösterir (Büyüköztürk, 2018). Bu araştırma için 
ölçeklerin Cronbach’s alpha değerlerine bakıldığında "Lisans Öğrencilerinin Liderlik Davranışlarına İlişkin Öz Algı Ölçeği” için toplam puan .86, alt boyutları; "katılımcı lider" .72, "kendine güvenen lider" .62, "ilkeli lider” .75, "kararlı lider” .67’dir. "Yaratıcı Kişilik Özellikleri Ölçeği” için Cronbach’s alpha değerleri ise bu araştırma için toplam puanda .78, alt boyutları; "amaç yönelimlilik" .75, "içsel motivasyon" .76, "merak" .84 ve "risk alma" .60 olarak bulunmuştur.

\section{BULGULAR}

Spor bilimlerinde öğrenim gören üniversite öğrencilerinden elde edilen bulgular aşağıda tablolar halinde verilmiştir.

Tablo 1. Ölçeklere ait ortalama, standart sapma, çarpıklık, basıklık, minimum ve maksimum değerleri

\begin{tabular}{llllllll}
\hline Ölçekler ve Alt Boyutları & $\begin{array}{l}\text { Madde } \\
\text { Sayısı }\end{array}$ & Ort. & Ss & Çarpıklık & Basıklık & Min. & Mak. \\
\hline $\begin{array}{l}\text { Liderlik Davranışlarına ilişkin } \\
\text { Öz Algı Ölçeği }\end{array}$ & 20 & & & & & & \\
Katılımcı Lider & 6 & 24.05 & 3.472 & -.461 & .167 & 11 & 30 \\
Kendine Güvenen Lider & 4 & 14.62 & 2.786 & -.349 & -.192 & 6 & 20 \\
İlkeli Lider & 6 & 26.01 & 3.146 & -.885 & .754 & 13 & 30 \\
Kararlı Lider & 4 & 15.85 & 2.637 & -.529 & .480 & 6 & 20 \\
\hline Yaratıcı Kişilik Özellikleri Ölçeği & 17 & 63.08 & 8.831 & -.026 & -.411 & 39 & 83 \\
Amaç Yönelimlilik & 5 & 16.43 & 4.046 & -.134 & -.472 & 7 & 25 \\
İçsel Motivasyon & 5 & 20.57 & 3.434 & -1.002 & 1.211 & 7 & 25 \\
Merak & 3 & 10.89 & 3.103 & -.403 & -.620 & 3 & 15 \\
Risk Alma & 4 & 15.18 & 3.167 & -.486 & -.125 & 5 & 20 \\
\hline
\end{tabular}

Tabloda da görüldüğü gibi, ölçekten alınabilecek en yüksek puanlar düşünüldüğünde öğrencilerin "katılımcı lider" ve "ilkeli lider" boyutlarındaki öz algılarının yüksek olduğu tespit edilmiştir. Öğrencilerin YKÖÖ toplam puan ortalaması 63.08'dir. YKÖÖ’nden alınabilecek en yüksek puan değerinin 85 olduğu göz önüne alındığında spor bilimlerinde eğitim alan öğrencilerin orta düzeyin üzerinde bir yaratıcı kişilik özelliklerine sahip oldukları söylenebilir. Değişkenlerden elde edilen puanların normal dağılım özelliği için çarpıklık (skewness) ve basıklık (kurtosis) değerlerinin \pm 1.5 aralığında olduğu tespit edilmiş (Tabachnick ve Fidell, 2013) ve bu doğrultuda iki ölçekten de elde edilen verilerin normal dağıldığı varsayılmıştır.

Tablo 2. Liderlik davranışlarına ilişkin öz algı ile yaratıcı kişilik özellikleri arasındaki ilişki (n=236)

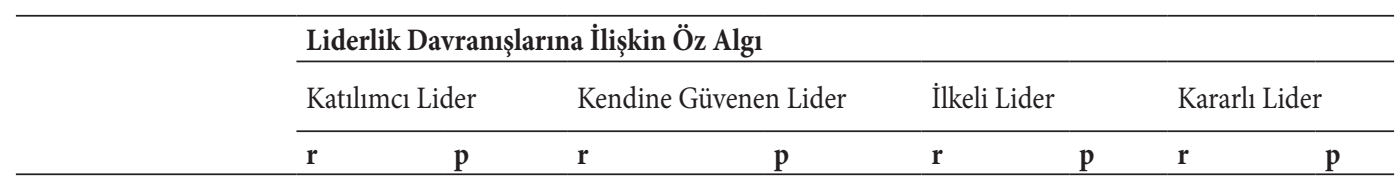




\begin{tabular}{|c|c|c|c|c|c|c|c|c|}
\hline $\begin{array}{l}\text { Yaratıcı Kişilik } \\
\text { Özellikleri }\end{array}$ & $.326^{\star *}$ & .000 & $.237^{\star *}$ & .000 & $.476^{\star *}$ & .000 & $.303^{* *}$ & .000 \\
\hline Amaç Yönelimlilik & $.171^{* *}$ & .008 & .029 & .652 & $.293^{* *}$ & .000 & $.156^{\star}$ & .016 \\
\hline Motivasyon & $.357^{\star *}$ & .000 & $.310^{\star \star}$ & .000 & $.410^{* *}$ & .000 & $.211^{\star *}$ & .001 \\
\hline Merak & $.141^{\star}$ & .031 & .030 & .649 & $.188^{\star *}$ & .004 & $.204^{* *}$ & .002 \\
\hline Risk Alma & $.164^{*}$ & .011 & $.259^{* *}$ & .000 & $.323^{* *}$ & .000 & $.216^{* *}$ & .001 \\
\hline
\end{tabular}

${ }^{*} \mathrm{p}<.05^{* *} \mathrm{p}<.01$

Yapılan Pearson Korelasyon analizi sonucunda, öğrencilerin LDİÖAÖ alt boyutlarından aldıkları puanlar ile YKÖÖ’nden aldıkları puanlar arasında istatistiksel olarak pozitif yönde anlamlı korelasyonlar olduğu tespit edilmiştir. Elde edilen bu bulguya göre, öğrencilerin yaratıcı kişilik özellikleri ile liderlik davranışlarına ilişkin öz algılarının bazı alt boyutlar için birlikte arttığı söylenebilir.

\section{TARTIŞMA}

Bu çalışmada, spor bilimlerinde öğrenim gören üniversite öğrencilerinin liderlik davranışlarına ilişkin öz algıları ile yaratıcı kişilik özellikleri arasındaki ilişki incelenmeye çalışılmıştır. Bu doğrultuda belirlenen araştırma sorusunun yanıtı olarak, spor bilimleri öğrencilerinin "Liderlik Davranışlarına İlişkin Öz Algıları Ölçeği” puanları ile "Yaratıcı Kişilik Özellikleri Ölçeği” puanları arasında bazı boyutlar için orta düzeyde, pozitif ve anlamlı ilişkiler olduğu bulunmuştur (Tablo 2). Bizim çalışmamızın aksine Çoban’ın (1999) yöneticiler üzerinde yaptığı araştırmada liderlik tarzları ile yaratıcılık arasında anlamlı bir ilişki olmadığı tespit edilmiştir. Bakan ve Büyükmeşe’nin (2010) eğitim kurumu yöneticilerinin liderlik türleri ve güç kaynakları ile ilgili yaptıkları araştırma sonucunda değişimlere adapte olamayan, kendini sürekli geliştirerek yenilik yaratmayan, eskimiş ilkelerin yerine yeni ilkeler geliştirmeyen ve bu konuda gereken riskleri göze almayan yöneticilerin başarısız olduğu görüşüne ulaşılmıştır. Bizim çalışmamız da bu çalışmayı destekler nitelikte sonuçlara ulaşmıştır. Bir başka ifade ile yaratıcı kişilik özellikleri bulunan ve bunları geliştirecek olan bireylerin liderlik davranışlarına yönelik öz algılarının da olumlu yönde bir değişime uğrayacağı söylenebilir. DiLiello ve Houghton (2011) da yaratıcılık ve öz liderliğin geleceğin örgütsel liderlik kapasitesini birlikte artırabilecek önemli bir husus ve yaratıcı ve yenilikçi olmaya ayak uyduran çalışanların örgütlerine daha faydalı olacaklarını belirtmektedir. Bu bağlamda yapılan bu araştırmada üniversite eğitimi alan öğrencilerin yaratıcı kişilik ve liderlik davranışları öz algılarının birlikte arttığı ve orta düzeyde anlamlı bir ilişki bulunduğu göz önüne alındığında, öğrencilerin yaratıcı kişilik ve liderlik öz algılarının arttırılmasına yönelik çalışmaların ya da derslerinin olması gelecekte çalışacakları kurumlarda daha başarılı olmak adına faydalı olacağı düşünülmektedir.

Yukl’a (1989) göre yaratıcı ve dürüst bir kişilik ile sosyal ve katılımcı bir ruha sahip olma bir liderde bulunması gereken özelliklerdir. Yaptığımız bu çalışmada da öğrencilerin "Yaratıcı Kişilik Özellikleri Ölçeği” toplam puanı ve "katılımcı lider" alt boyut puanı arasında orta düzeyde pozitif yönde anlamlı bir ilişki görülmüştür. Katılımcı liderin en önemli kişilik özelliklerinden birisinin yaratıcı kişilik özelliği olduğu ve örgütsel yaratıcılığa önem verdiği söylenilebilir. 
Yapılan çalışmada "Yaratııı Kişilik Özellikleri Ölçeği” toplam puanı ve "Liderlik Davranışlarına İlişkin Öz Alg 1 Ölçeği” alt boyutlarından "kendine güvenen lider" alt boyutuyla düşük düzeyde pozitif yönde anlamlı bir ilişki olduğu saptanmıştır. Alkın ve Ünsar (2007) bir liderin güven uyandırmasının ön şartının özgüven olduğunu belirtmişlerdir. Liderleri kendine güvenen ve paylaşılan hedeflere nasıl ulaşılacağını bilen kişiler olarak algılayan izleyicilerin lidere güvenlerinin artacağı ve onun stratejisini gerçekleştirebilmek için gönülden çalışacaklarını belirtmektedirler.

Bulgulara bakıldığında "Yaratıcı Kişilik Özellikleri Ölçeği”" toplam puanı ile liderlik davranışlarına ilişkin öz alg1 alt boyutu olan "ilkeli lider" arasındaki ilişki, diğer alt boyutlara ve toplam puana göre daha yüksek çıkmıştır. Bu doğrultuda ilkeli lider davranışına sahip öğrencilerin yaratıcı kişilik özelliklerinin de gelişmiş olduğu söylenebilir.

"Yaratıcı Kişilik Özellikleri Ölçeğinin" toplam puanı ve "Liderlik Davranışlarına İlişkin Öz Algı Ölçeğinin" "kararlı lider" alt boyut puanları arasında orta düzeyde ve pozitif yönde anlamlı bir ilişki saptanmıştır. Kararların etkili bir şekilde verilmesi gerektiği düşünüldüğünde, bir liderin tüm liderlik stillerinden tamamen haberdar olması gerekir. Böylece esnek olabilir ve duruma özgü stiller uygulayabilir. Karar almada esneklik, duruma farklı bir bakış açısı getirme, yenilikçilik ve yeni fikirlerle risk almaya istekli olma, iyi konumlandırılmış bir iş organizasyonu oluşturabilen yaratıcı liderlerin özellikleridir (Bosiok, 2013). Bahsedilen çalışmada savunulan görüş bizim bulgumuzu destekler niteliktedir. Bir liderin kararlı olma özelliği onun yaratıı kişilik özelliklerinin yüksek düzeyde olmasından kaynaklanıyor olabilir.

Araştırmada kullanılan ölçeklerin alt boyutları arasındaki ilişkiler incelendiğinde (Tablo 2) yaratıcı kişilik özelliklerinden "amaç yönelimlilik" ile "katılımcı, ilkeli ve kararlı liderlik" arasında düşük düzeyde, bir başka yaratıcı kişilik özelliği olan "motivasyon" ile "katılımcı, kendine güvenen ve ilkeli liderlik" öz algıları arasında orta, "kararlı lider" öz algısı arasında düşük düzeyde pozitif yönde, yaratıcı kişilik özelliklerinden "merak" ile "katılımcı, ilkeli ve kararlı lider" öz algısı arasında düşük düzeyde, pozitif yönde ve yaratıcı kişilik özelliklerinden "risk alma" ile "katılımcı, kendine güvenen ve kararlı lider" öz algısı arasında düşük, "ilkeli lider" öz algısı arasında ise orta düzeyde pozitif yönlü ilişkiler saptanmıştır. Önen ve Kanayran’ın (2015) araştırmasında, liderin başlıca görevlerinden birinin çalışanların örgütsel amaçlar doğrultusunda motivasyonlarını sağlamak olduğu vurgulamıştır. Çalışanları isteklendirmeye ve örgütte verimli çalışmaya yönelik kişisel ihtiyaçların karşılanması süreci olarak motivasyon sayesinde, liderler ve çalışanlar arasında bir etkileşim başlatılarak ve örgütsel hedefler doğrultusunda iş birliği yapılarak yüksek bir performansa ulaşmanın mümkün olabileceği ileri sürülmüştür. Bizim çalışmamızda öğrencilerin liderlik davranışına ilişkin öz algıları ile yaratıcı kişilik özelliklerinden motivasyon arasında orta düzeyde ilişki bulunması yapılan çalışmaları destekler niteliktedir. Dolayısıyla, liderin örgütte çalışanların motivasyonunu artırarak onları daha etkin ve verimli hale getirmesinin anahtar bir rol oynayacağı düşünülmektedir. Bass’a (1990) göre, riske giren yöneticiler/liderler, riske girmeyenlere oranla daha ikna edici, etkileyici ve daha güven vericidirler. Erarslan’ın (2006) yaptığı çalışmaya göre risk alma, liderin geri adım atamayacağı bir yola girme cesaretini ifade eder. Liderin, önüne çıkan fırsatları iyi değerlendirmesi ve kullanmak zorunda olması önemlidir. Ortamın ve geleceğin belirsizliğine rağmen, lider, fırsat maliyetlerinin yanı sıra 
potansiyel başarısızlık maliyetini de hesaba katmak durumundadır. Bu anlamda araştırmamızda risk alma ile ilgili elde edilen bulgu diğer araştırmacıları destekler niteliktedir. Bir başka ifade ile öğrencilerin liderlik öz algıları yükseldikçe risk alma özelliklerinin de yükselmesi onların gelecekte iyi birer yönetici ya da lider özellikleri sergileyebileceği anlamına gelebilir. Liderlik için yapılan tanımlardan da hatırlanabileceği üzere risk alabilen, insanları amaçları doğrultunda etkileyebilen bireyler lider kişiler olarak geçmektedir. Bu doğrultuda, risk almanın liderlik davranışları ile ilişkili bir unsur olduğunu söyleyebiliriz.

\section{SONUÇ ve ÖNERİLER}

Bu çalışmada spor bilimleri fakültesinde eğitim alan öğrencilerin liderlik davranışlarına ilişkin öz algıları ile yaratıcı kişilik özellikleri arasındaki ilişki incelenmiştir. "Yaratıcı Kişilik Özellikleri Ölçeği” toplam puanı ve "Liderlik Davranışlarına İlişkin Öz Algı Ölçeği” alt boyutlarından "katılımcı lider", "ilkeli lider" ve "kararlı lider" arasında orta düzeyde ve pozitif yönde anlamlı ilişkiler, "kendine güvenen lider" alt boyutuyla ise düşük düzeyde ve pozitif yönde anlamlı bir ilişki saptanmıştır. Alt boyutlar arasında orta düzeyde pozitif yönlü anlamlı ilişkilere bakılacak olursa "motivasyon" ile "katılımcı lider", "kendine güvenen lider" ve "ilkeli lider" arasında ve "risk alma" ile de "ilkeli lider" arasında orta düzeyde pozitif yönlü ilişki saptanmıştır.

Gündelik hayatın ve teknolojik gelişmelerin getirdiği yeniliklere uyum sağlamak, mevcut problemlere yeni yaklaşımlar getirmek günümüz şartlarında oldukça önemli bir noktaya gelmiştir. Yeni koşullara ayak uydurmak için ortaya konan yaratıcı fikirler, yenilikçi adımlar, dinamik faaliyetler iş dünyasında ön plana çıkma ve diğer insanların önüne geçmek açısından sahip olunan kişisel özellikler ve liderlik davranışları oldukça önemlidir. Öğrencilerin liderlik özelliklerinin lisans döneminde gelişim gösterdiği ve öğrencileri güçlendirip donanımlı hale getirdiği çalışmalar tarafından da desteklenen bir konudur. Üniversite eğitiminin sağladığı imkanlar, projeler, çalışmalar ise öğrencilerin yaratıcı kişilik özelliklerini destekleyen fırsatlardır. Üniversite sonrası meslek hayatının başladığı düşünüldügünde eğitim sürecinde öğrencilerin kendilerini kişisel özellikler açısından ne kadar tanıdığı ve edindikleri kazanımların ne derece farkında oldukları oldukça önemlidir. Bu nedenle bu araştırmanın konusu olan spor bilimleri fakültesi öğrencilerin liderlik davranışlarına ilişkin öz algıları ile yaratıcı kişilik özellikleri arasındaki ilişkiyi ortaya koymak öğrencilerin kendilerine karşı liderlik algılarını ve yaratıcılıklarını geliştirmesi açısından önemlidir.

$\mathrm{Bu}$ çalışma, araştırmaya katılan ve Spor Bilimleri Fakültesi’nde öğrenim gören lisans öğrencileri ile sınırlıdır. $\mathrm{Bu}$ araştırmada kullanılan ölçüm araçları arasındaki ilişkiyi inceleyen bir çalışmaya rastlanılmaması ve spor bilimleri alanında konu ile ilgili çok az sayıda çalışma bulunması araştırma verilerinin diğer çalışmalar ile karşılaştırılmasını güçleştirmiştir.

Gelecek çalışmalar için üniversitelerin spor bilimleri fakültelerinde eğitim gören öğrencilerin yaratıcı kişilik özellikleri ile liderlik davranışlarına ilişkin öz algıları arasındaki ilişki incelenerek daha fazla örneklem grubuna ulaşılabilir. Bu konu ile ilgili spor alanındaki farklı meslek grupları üzerinde araştırmalar yapılabilir. Spor bilimleri fakültesi öğrencilerinin liderlik davranışlarına 
ilişkin öz algıları ve yaratıcı kişilik özellikleri arasındaki ilişkinin orta düzeyde çıkmasının nedenleri araştırılabilir.

Yazar Notu: Bu çalışma 25-28 Nisan 2019 tarihleri arasında Alanya-Türkiye’de düzenlenen 2. Uluslararası Herkes İçin Spor ve Wellness Kongresi'nde sözel bildiri olarak sunulmuştur. Bu çalışmada kullanılan verilerin 2020 yılı öncesine ait olduğu ve etik kurallara uyulduğu araştırmacılar tarafından onaylanmıştır.

\section{KAYNAKLAR}

Alkın, C., ve Ünsar, S. (2007). Liderlik özellikleri ve davranışlarının belirlenmesi üzerine bir araştırma. Gazi Üniversitesi İktisadi ve İdari Bilimler Fakültesi Dergisi, 9 (3), 75-94.

Amabile, T. M., Schatzel, E. A., Moneta, G. B., \& Kramer, S. J. (2004). Leader behaviors and the work environment for creativity: Perceived leader support. The Leadership Quarterly, 15(1), 5-32. Doi: 10.1016/j.leaqua.2003.12.003

Astin, A. W., \& Astin, H. S. (2000). Students have the power to lead. Chapter 3 (Eds: Alexander W. Astin and Helen S. Astin, in: Leadership Reconsidered: Engaging Higher Education in Social Change), p. 18, W.K. Kellogg Foundation.

Atar, E. ve Özbek, O. (2009). Beden Eğitimi Ve Spor Yüksekokulu Öğrencilerinin Liderlik Davranışları. SPORMETRE Beden Eğitimi ve Spor Bilimleri Dergisi, 7(2), 51-59.

Bakan, İ. (2008). Örgüt Kültürü Ve Liderlik Türlerine İlişkin Algılamalar İle Yöneticilerin Demografik Özellikleri Arasındaki İlişki: Bir Alan Araştırması. KMU İİF Dergisi, 10(14), 13-40.

Barron, F., \& Harrington, D. M. (1981). Creativity, Intelligence, And Personality. Annual Review of Psychology, 32(1), 439-476. Doi: 10.1146/annurev.ps.32.020.181.002255

Basadur, M. (2004). Leading Others To Think Innovatively Together: Creative Leadership. The Leadership Quarterly, 15(1), 103-121. Doi: 10.1016/j.leaqua.2003.12.007

Bass, B. M., \& Stogdill, R. M. (1990). Bass \& Stogdill's Handbook Of Leadership: Theory, research, and managerial applications. Third Edition, New York: The Free Press.

Bosiok, D. (2013). Leadership styles and creativity. Online Journal of Applied Knowledge Management, 1(2), 6477.

Bozyiğit, E. (2019). Sports manager training and leadership behaviors. Journal of Education and Learning, 8(2), 248-255. Doi: 10.5539/Jel.V8n2p248

Bozyiğit, E., ve Sartık, Ş., (2018). Yöneticilik Eğitimi Alan Üniversite Öğrencilerinin Liderlik Davranışlarının İncelenmesi. Atatürk Üniversitesi Beden Eğitimi ve Spor Bilimleri Dergisi, 20(3), 47-59.

Burke, W. W., \& Litwin, G. H. (1992). A causal model of organizational performance and change. Journal of Management, 18(3), 523-545. Doi: 10.1177/014.920.639201800306

Büyüköztürk, Ş. (2018). Sosyal bilimler için veri analizi el kitabı: İstatistik, araştırma deseni, SPSS uygulamaları ve yorum. Ankara: Pegem Akademi.

Çoban, S. (1999). Yöneticilerin yaratıcılı düzeyleri ile liderlik tarzları arasındaki ilişki. Yayımlanmamış Doktora Tezi, İstanbul Üniversitesi, Sosyal Bilimler Enstitüsü, İşletme Personel Yönetim ve Organizasyon Anabilim Dalı, İstanbul.

Değirmenci, c. H. (2012). 21. Yüzyılda Liderlik ve İş Dünyası. İstanbul: Bilge Karınca Yayıncllık.

Demir Uslu, Y. (2011). Örgütlerde Yönetsel Etkinliğe Ulaşmada Yeni Bir Yaklaşım: Yaratıcı liderlik. Sosyal Ekonomik Araştırmalar Dergisi, 11(22), 419-444. 
DiLiello, T. C., \& Houghton, J. D. (2006). Maximizing organizational leadership capacity for the future toward a model of self-leadership, innovation and creativity. Journal of Managerial Psychology, 21(4), 319-337. Doi: $10.1108 / 026.839 .40610663114$

Eraslan, L. (2006). Liderlikte Post-modern bir paradigma: Dönüşümcü liderlik. Journal of Human Sciences, 1(1), $1-32$.

Erçetin, Ş. (2000). Lider Sarmalında Vizyon. 2. Baskı, Ankara: Nobel Yayın Dağıtım.

Karasar, N. (2012). Bilimsel Araştırma Yöntemi. Ankara: Nobel Akademik Yayıncılık.

Keskin, N., ve Gündüz, E. (2019). Yaratıcı Liderlik Geliştirmede Enneagram Öğretisinin Rolü. Akademik Platform Eğitim ve Değişim Dergisi, 2(2), 41-58.

Kızıloğlu, A., Tabak, A., ve Erkenekli, M. (2012). Örtük liderlik kuramı. İçinde: A. Tabak, H. Şeşen ve T. Türköz (eds), Liderlikte güncel yaklaşımlar. 1. Baskı, Ankara: Detay Yayıncılık.

Korkmaz, M. (2006). Okul yöneticilerinin kişilik özellikleri ile liderlik stilleri arasındaki ilişki. Kuram ve Uygulamada Eğitim Yönetimi Dergisi, 12(2), 199-226.

Mutlu, T. O., Şentürk, H. E., Akoğlu, H. E., Çetinkaya, A., ve Ağılönü, A. (2020). Spor bilimleri fakültesi öğrencilerinin liderlik davranışlarının incelenmesi. Sportif Bakış: Spor ve Eğitim Bilimleri Dergisi, 7(SI2), 25-38. Doi: 10.33468/sbsebd.131

Önen, S. M., ve Kanayran, H. G. (2015). Liderlik Ve Motivasyon: Kuramsal Bir Değerlendirme. Birey ve Toplum Sosyal Bilimler Dergisi, 5(2), 43-64.

Özbek, O., ve Kızılyallı, M. (2017). Lisans öğrencilerinin liderlik davranışlarına ilişkin öz algıları: ölçek geliştirme çalışmasi. Journal of Human Sciences, 14(4), 4112-4122.

Öztürk, M., ve Zembat, R. (2015). Okul öncesi yöneticilerinin yaratıcı liderlik özellikleri ile okul iklimi arasındaki ilişkinin incelenmesi. The Journal of Academic Social Science Studies, 31, 455-467. Doi: 10.9761/JASSS2653

Rolling Jr, J. H. (2016). Creative Leadership. Art Education, 69(2), 4-5. Doi: 10.1080/00043.125.2016.1141640

Scott, D. S. (2014). Contemporary Leadership in Sport Organizations. Champaign, IL: Human Kinetics, Inc.

Soemartono, T. (2014). Reconstruction of Education Policy in Jembrana Bali, Best Practices of Creative and Innovative Leadership Using Soft Systems Methodology-Based Action Research. Procedia-Social and Behavioral Sciences, 115, 269-282. Doi: 10.1016/j.sbspro.2014.02.435

Sternberg, R. J., Kaufman, J. C., \& Pretz, J. E. (2003). A propulsion model of creative leadership. The Leadership Quarterly, 14(4-5), 455-473.

Stogdill, R. (1974). Handbook of leadership: A survey theory and research. New York: Free Press.

Stoll, L., \& Temperley, J. (2009a). Creative Leadership: a Challenge of Our Times. School Leadership \& Management, 29(1), 65-78. Doi:10.1080/136.324.30802646404

Stoll, L., \& Temperley, J. (2009b). Creative leadership teams. Management in Education, 23(1), 12-18. Doi:10.1177/089.202.0608099077

Şahin, F., ve Danışman, Ş. (2017). Yaratıı kişilik özellikleri ölçeği: Güvenilirlik ve geçerlik çalışması. Karabük Üniversitesi Sosyal Bilimler Enstitüsü Dergisi, 7 (2), S.750-763.

Tabachnick, B. G., \& Fidell, L. S. (2013). Using multivariate statistics. Boston, Pearson.

TDK (2020). Yaratıcı düşünme. Türk Dil Kurumu Sözlükleri, Eğitim Terimleri Sözlüğü, 1974. https://sozluk.gov. tr/ (Erişim tarihi: 1 Nisan 2020)

Tengilimoğlu, D. (2005). Kamu ve özel sektör örgütlerinde liderlik davranışı özelliklerinin belirlenmesine yönelik bir alan çalışması. Elektronik Sosyal Bilimler Dergisi, 4(14), S.1-16. 
Türksoy, A. (2008). Futbolda sporcu tatmini ile antrenörlerden beklenilen ve gerçekleşen liderlik davranışlarının tespiti. Yayımlanmamış Doktor Tezi, Marmara Üniversitesi, Sağlık Bilimleri Enstitüsü, Beden Eğitimi ve Spor Ana Bilim Dalı, İstanbul.

Uzunçarşılı, Ü., ve Özdayı, N. (1997). Okul yöneticilerinin yaratıcılık ile liderlik özelliklerinin araştırılması. M.Ü. Atatürk Eğitim Fakültesi Eğitim Bilimleri Dergisi, Sayı: 9 Sayfa: 359-367.

Yukl, G. (1989). Managerial leadership: A review of theory and research. Journal of Management, 15(2), 251-289, Doi: $10.1177 / 014.920 .638901500207$

Zel, U. N. (2002). Kişilik ve liderlik. Ankara: Seçkin Yayınevi.

Zimmerman Oster, K., \& Burkhardt, J. C. (2000). Leadership in the making: Impact and insights from leadership development programs in U.S. colleges and universities. Executive Summary. W.K. Kellogg Foundation. 